\title{
Robots in service experiences: negotiating food tourism in pandemic futures
}

\author{
Francesc Fusté-Forné and Stanislav Ivanov
}

\begin{abstract}
Purpose - This research discusses the role of service robots in gastronomic and dining experiences in a post-coronavirus disease (COVID) world.

Design/methodology/approach - The research note draws on secondary data to analyse the use of robots as an important mechanism to address the impacts of global disease outbreaks on the food industry, as related to hospitality and tourism.

Findings - Hospitality and tourism services are highly affected by the current travel bans, lockdowns and health-related rules that have emerged to manage the current pandemic (COVID-19). This research showcases the role of service robots in food encounters in hospitality and tourism as agents that contribute to safe and innovative experiences.

Originality/value - This research note explores how the use of robots in tourism futures will not only transform food experiences, but it is also critical to sustainable development of communities and destinations in a future that will continuously have to deal with disease outbreaks and pandemics with continued travel mobilities.
\end{abstract}

Keywords Community resilience, Restaurant industry, Safety, Service robot

Paper type Research paper

\section{Introduction}

A quarter of a century ago, Pransky (1996) raised the need to define what service robots are and how they can contribute to human well-being. She highlighted that "unlike industrial robots, which are typically found in manufacturing environments, service robots (or "serve us" robots as I[she] like to refer to them) will cater to the masses, millions of end-users in a variety of settings from the hospital to the home, from restaurants to offices" (p. 4). According to the International Federation of Robotics (2020), a service robot is a type of autonomous robot that performs useful tasks for humans without human intervention. In a more specific sense, service robots are described as social agents that can replace human providers in service experiences (Van Doorn et al., 2017).

Research on the relationship between automation services and tourism has been rapidly growing in recent years (Belanche et al., 2020; Cain et al., 2019; Ivanov and Webster, 2019; Kuo et al., 2017; Murphy et al., 2017). The adoption of automation services in tourism has also led to a new service landscape where robots are gaining both practical and research attention (De Kervenoael et al., 2020; Mende et al., 2019; Qiu et al., 2020). According to Ivanov et al. (2019), robots are used in service contexts "as receptionists, bellboys, museum guides, concierges, housekeepers, waiters and bartenders, luggage-storage staff, delivery robots, butlers and room service assistance, chatbots and online customer support staff" (2019, p. 503). In particular, service robots are being adopted by restaurants to provide not only safe but also unique experiences in a pandemic context (see for example Albrecht, 2020; Avery, 2020; Berger, 2020; DeBos, 2020; Seyitoğlu and Ivanov, 2020c). This includes robots that can take orders, cook and serve food. For example, the
Francesc Fusté-Forné is based at the Universitat de Girona, Girona, Spain. Stanislav Ivanov is based at the Varna University of Management, Varna, Bulgaria.
Received 26 October 2020

Revised 8 April 2021 19 April 2021

Accepted 5 May 2021

(c) Francesc Fusté-Forné and Stanislav Ivanov. Published in Journal of Tourism Futures.

Published by Emerald Publishing Limited. This article is published under the Creative Commons Attribution (CC BY 4.0) licence. Anyone may reproduce, distribute, translate and create derivative works of this article (for both commercial and non-commercial purposes), subject to full attribution to the original publication and authors. The full terms of this licence may be seen at http:// creativecommons.org/licences/ by/4.0/legalcode 
implementation of robot bartenders (Royal Caribbean International, 2016) or the adoption of robot chefs (Doyle, 2018) create memorable experiences in service encounters (FustéForné, 2021).

The current coronavirus disease (COVID-19) pandemic raises new questions about this alliance between robotics and hospitality as a technological solution for the foodservice industry and food tourism experiences (Hong Zhu and Ping Chang, 2020; Lee et al., 2018; Seyitoglu and Ivanov, 2020a; Zemke et al., 2020), especially in a future where global disease outbreaks and pandemics are anticipated to be among the "new normal" (Jamal and Budke, 2020) along with, and possibly exacerbated by, climate change (Dogru et al., 2019; Semenza and Ebi, 2019). This research note draws on the published research literature and news media to discuss the opportunities and challenges presented by the use of robots as an important mechanism to address the impacts of pandemics on the hospitality and tourism industry.

\section{Service robots in pandemic times and food tourism futures}

Food services as part of the tourism system are vulnerable to natural hazards such as pandemics (Dube et al., 2020). The hospitality industry is one of the largest affected sectors (see, for example, Gössling et al., 2021) and measures to ensure food safety, the safety of visitors and service providers, and control risk perceptions are crucial (Handley, 2020). The implementation of robots in the face of global disease outbreaks must be effective to match individual and social needs (Lafranca, 2020). Robots can provide a 24/7 service (Park, 2020), and their design is vital to the effective adoption of service robots by gastronomic and dining experiences (Hong Zhu and Ping Chang, 2020). In this sense, according to Seyitoglu and Ivanov (2020a), appearance and functionalities emerge as significant attributes when planning a robotic experience. For example, "a humanoid robot can be used as a host inviting and entertaining guests in the restaurants, while a non-humanoid robot could be used to deliver the food" (p. 11).

Previous studies have underlined that demographic changes and patterns emerge as the biggest drivers of service automation in tourism (Webster and Ivanov, 2020). Nonetheless, the global outbreak has changed this scenario: now COVID-19 has taken over as the most important driver of automation (Zeng et al., 2020) and contact-free technologies including robotization to limit virus spread by front-line service providers are and will be of critical importance (Ivanov et al., 2020; Seyitoğlu and Ivanov, 2020b, c). The pandemic has boosted robots to manage actual and perceived risk in the labour-intensive hospitality industry (Berreby, 2020). These include visitor concerns about food contamination, infection transmission during service provision and the potential lack of personal protective equipment to safeguard the health of frontline service providers.

Progress in the development of service robots, and the potential of their increased use as frontline providers to reduce human-to-human contact, has significant implications for gastronomic and food services, as observed in Figure 1. COVID-19 is speeding up the use of robots (Thomas, 2020) for food safety and as an avenue to provide biosecurity to tourism stakeholders (Ivanov et al., 2020). Automation technologies will be increasingly important for competitive advantage in hospitality and (food) tourism (Fusté-Forné and Hussain, 2021; Kuo et al., 2017). In particular, their use in enabling safe experiences is a prerequisite to rebuild tourism and proactively prepare for future disease outbreaks and pandemics that will continue to affect domestic and international tourism futures (Ivanov et al., 2020). This raises important questions for research and practice. What are visitors' experiences of robots in tourism and how are visitors perceiving robots in the food experiences in the context of the hospitality and tourism industry?

While previous studies (see Ivanov and Webster, 2019) revealed that customers find robots in a restaurant context more suitable in roles such as cleaning, providing information or 


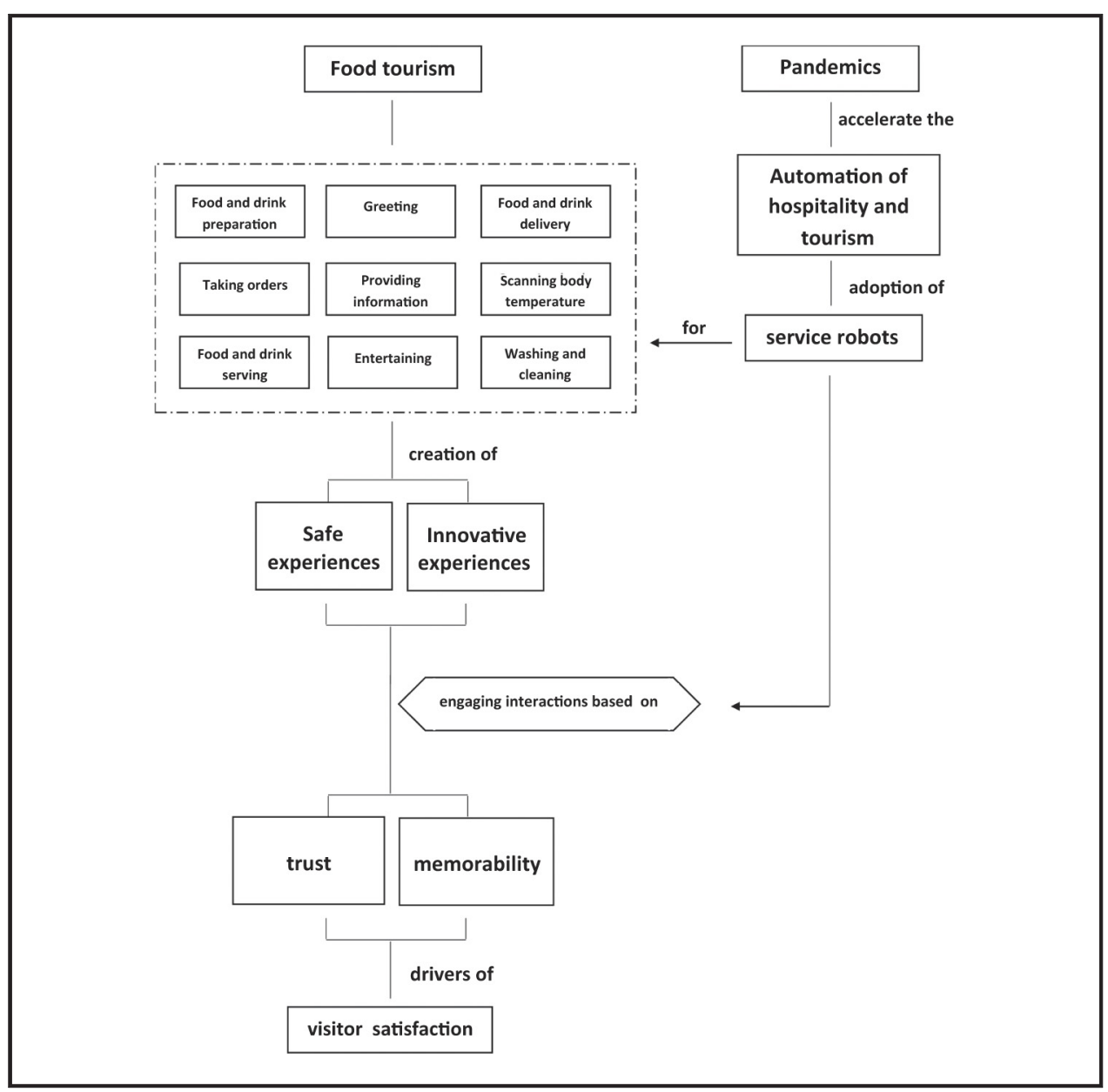

taking orders, robots are also adopted to cook and serve food (Zhu and Chang, 2020). Practical examples demonstrate that robotization can foster not just competitive advantage but also personalization in food tourism experiences (De Kervenoael et al., 2020; Tuomi et al., 2020). According to Fusté-Forné and Jamal (2021), "roles in service robotics range from automation for novelty, for example, a restaurant that places a personal robot assistant on every table as a way to create a unique experience, to automation for improving service quality, such as in delivering orders efficiently and punctually" (p. 45).

Several examples show the kinds of robot-delivered experiences emerging in restaurants, with a primary goal to serve up safety (Lang, 2021). A simple change refers to the overall implementation of digital menus and Quick Response (QR) codes which represent a safe alternative to view menus and order (Littman, 2021). As automation and technology lead the restart of culinary experiences amidst a global pandemic, more and more service robots are adopted for delivering gastronomic and dining experiences, for example, as robot waiters (Hontoria, 2020). In Maastricht, a restaurant hired humanoid robots to greet customers, scan body temperatures or serve drinks to reduce person-to-person contact (Brady, 2020). Robotic food delivery is rapidly implemented by Food and Beverage (F\&B) outlets as well (Albrecht, 2021), including meal delivery robots in airport restaurants (Baskas, 2021). A growing sophistication is especially observed in the rise of a robot that can cook (Wiggers, 2020) which will also drive gastronomic robotization in tourism futures. 
The current pandemic has severely impacted tourism, and the industry is scrambling to embrace new directions and innovations to recover and reassure travellers of safe and enjoyable experiences at their destination (UNWTO, 2020). From an academic perspective, Choi et al. (2021) explored how service robots deliver engaging customer experiences. Within the context of tourism, they reveal the influence of cultural background on how service experience provided by robots is perceived. Furthermore, Berezina et al. (2019) state that service automation in restaurants positively impacts visitor satisfaction. Service robots must not only provide safety in gastronomic and dining experiences but also trust (see, for example, Seyitoğlu and Ivanov, 2020b; Tussyadiah et al., 2020) which, together with the speedy advancement of technology, will also lead to increased robotization of food and gastronomic experiences in the future.

\section{Conclusion}

While hospitality has always been a "high-touch" industry, it has moved to "high-tech" dominant servicescapes (Benckendorff et al., 2005) and a rapid robotization of experiences (Zeng et al., 2020) due to the impact of the COVID-19 pandemic on tourism systems. The COVID-19 pandemic has shocked communities and destinations worldwide and put global threats to sustainable tourism futures. Global tourism faces an unprecented crisis which urges academics and practitioners to rethink many aspects of the industry, for example, host-guest encounters and service experiences. This research note has analysed service robots as a strategy to respond to global crises and to foster proactive responses in the hospitality and tourism industry. In particular, this research has discussed some of the challenges and opportunities facing food experiences in hospitality and tourism. Moving forward into (post-)pandemic futures involves rethinking travel and tourism for sustainability and resilience (Prayag, 2020; Nepal, 2020; Sigala, 2020), and an important aspect of this is service encounters and service provision. How will automation affect service-level jobs such as frontline hospitality providers? How will robotization affect the visitor experience? How will it affect food tourism and slow food practices that strive towards sustainability, safety and slow encounters between local producers, service providers and visitors? (see for example Fusté-Forné and Jamal, 2020).

Besides, how the service encounter notion of "hospitality" will be negotiated within this new robotic environment will be a crucial priority for future research and practice (Bowen and Morosan, 2018). Recent publications also indicate that service automation may lead to an anti-hospitality context derived from the implementation of robotics in economy-centred tourism development (Korstanje, 2020). The use of robots in tourism futures will transform (food) tourism experiences (Manthiou et al., 2020) and the huge impact of automation on the development of humanity requires that responsible robotics (Dignum, 2019; Van Wynsberghe and Sharkey, 2020) be put at the centre of the robotisation of tourism experiences. Developing ethical robotics arises as an important consideration for future research and practice (Bartneck et al., 2021; Fusté-Forné and Jamal, 2021). Responsibility is crucial in human-robot interactions and various researchers argue that service robots in service encounters must increase rapport building (Qiu et al., 2020) and improve on "human" technological skills (Tuomi et al., 2020). Further research needs to analyse the human dimension both from supply and demand perspectives as a crucial avenue to understand visitors' experiences of robots.

Also, recent research reveals that the development of automation and robotics in the hospitality and tourism industry needs to be scrutinised from an ethical and equity perspective (Gretzel et al., 2020; Jamal, 2019). Specifically, Müller (2020) argues that privacy or opacity should be further examined. By this Müller means that the complex and dynamic nature of robotics is urging a debate on the ethical issues derived from the planning and implementation of digital technologies in human-centred environments. Service providers in hospitality and tourism must not forget what "hospitality" means. While pandemic times threaten human-to-human contact in service encounters, robotics can and 
will continue to contribute to increase safety for service providers and visitors. But many questions arise as to what this means for hospitality and what are generally perceived to be co-created and co-consumed experiences. A critical priority in future research and practice also is to understand what constitutes fair and ethical human-robot interactions in service delivery and visitor experience in the hospitality and tourism context.

\section{References}

Albrecht, C. (2020), "OrionStar launched a new coffee robot in China", The Spoon, October 1, available at: https://thespoon.tech/orionstar-launched-a-new-coffee-robot-in-china/

Albrecht, C. (2021), "South Korea: Hyundai and Woowa brothers partner for delivery robots", The Spoon, March 22, available at: https://thespoon.tech/south-korea-hyundai-and-woowa-brothers-partner-fordelivery-robots/

Avery, D. (2020), "Al-powered robots take over South Korea's no brand burger restaurant by collecting orders, cooking and serving customers to limit human contact amid the coronavirus pandemic", Daily Mail, September 15, available at: www.dailymail.co.uk/sciencetech/article-8734717/Al-Robots-serverestaurant-customers-South-Korea.html

Bartneck, C., Lütge, C., Wagner, A. and Welsh, S. (2021), "Ethics in Al and robotics: a strategic challenge", in Bartneck, C., Lütge, C., Wagner, A. and Welsh, S. (Eds), An Introduction to Ethics in Robotics and Al, Springer, Cham, pp. 101-104.

Baskas, H. (2021), "Delivery robots to digital health apps: 5 ways your next airport visit could be contactless", USA Today, January 5, available at: www.usatoday.com/web-stories/delivery-robots-todigital-health-apps-5-ways-your-next-airport-visit-could-be-contactless/

Belanche, D., Casaló, L.V. and Flavián, C. (2020), "Frontline robots in tourism and hospitality: service enhancement or cost reduction?", Electronic Markets, Vol. ahead-of-print No. ahead-of-print, pp. 1-16, doi: 10.1007/s12525-020-00432-5.

Benckendorff, P., Moscardo, G. and Murphy, L. (2005), "High tech versus high touch: visitor responses to the use of technology in tourist attractions", Tourism Recreation Research, Vol. 30 No. 3, pp. 37-47, doi: 10.1080/02508281.2005.11081485.

Berezina, K., Ciftci, O. and Cobanoglu, C. (2019), "Robots, artificial intelligence, and service automation in restaurants", in Ivanov, S. and Webster, C. (Eds), Robots, Artificial Intelligence, and Service Automation in Travel, Tourism and Hospitality, Emerald Publishing, Bingley, pp. 185-219.

Berger, D. (2020), "The potential of automation for manufacturing and social distancing", The Boss Magazine, available at: https://thebossmagazine.com/automation-social-distancing

Berreby, D. (2020), "The pandemic has been good for one kind of worker: robots", National Geographic, September 3, available at: www.nationalgeographic.com/science/article/how-pandemic-is-good-forrobots

Bowen, J. and Morosan, C. (2018), "Beware hospitality industry: the robots are coming", Worldwide Hospitality and Tourism Themes, Vol. 10 No. 6, pp. 726-733, doi: 10.1108/WHATT-07-2018-0045.

Brady, S. (2020), "Robot waiters serve drinks and take temperatures at this Dutch restaurant", Lonely Planet, June 8, available at: www.lonelyplanet.com/articles/robot-waiters-netherlands

Cain, L.N., Thomas, J.H. and Alonso, M. Jr (2019), "From sci-fi to sci-fact: the state of robotics and Al in the hospitality industry", Journal of Hospitality and Tourism Technology, Vol. 10 No. 4, pp. 624-650, doi: 10.1108/JHTT-07-2018-0066.

Choi, Y., Oh, M., Choi, M. and Kim, S. (2021), "Exploring the influence of culture on tourist experiences with robots in service delivery environment", Current Issues in Tourism, Vol. 24 No. 5, pp. 717-733, doi: 10.1080/13683500.2020.1735318.

De Kervenoael, R., Hasan, R., Schwob, A. and Goh, E. (2020), "Leveraging human-robot interaction in hospitality services: incorporating the role of perceived value, empathy, and information sharing into visitors' intentions to use social robots", Tourism Management, Vol. 78, pp. 1-15, doi: 10.1016/j.tourman.2019.104042.

DeBos, C. (2020), "DaVinci Kitchen is cooking up a robotic pasta-making station", The Burn-In, September 15, available at: www.theburnin.com/startups/davinci-kitchen-robotic-pasta-making-station2020-09-15/ 
Dignum, V. (2019), Responsible Artificial Intelligence: How to Develop and Use Al in a Responsible Way, Springer, Cham.

Dogru, T., Marchio, E.A., Bulut, U. and Suess, C. (2019), "Climate change: vulnerability and resilience of tourism and the entire economy", Tourism Management, Vol. 72, pp. 292-305, doi: 10.1016/j.tourman.2018.12.010.

Doyle, T.B. (2018), "Go to downtown crossing for a meal cooked by a robot", Eater Boston, April 27, available at: https://boston.eater.com/2018/4/27/17290330/downtown-crossing-robotic-kitchen

Dube, K., Nhamo, G. and Chikodzi, D. (2020), "Climate change-induced droughts and tourism: impacts and responses of Western Cape Province, South Africa", Journal of Outdoor Recreation and Tourism, Vol. ahead-of-print No. ahead-of-print, 100319, doi: 10.1016/j.jort.2020.100319.

Fusté-Forné, F. (2021), "Robot chefs in gastronomy tourism: what's on the menu?", Tourism Management Perspectives, Vol. 37, 100774, doi: 10.1016/j.tmp.2020.100774.

Fusté-Forné, F. and Hussain, A. (2021), "We are open: understanding crisis management of restaurants as pandemic hits tourism", Journal of Hospitality, Vol. 3 No. 1, pp. 41-48, available at: http://htmjournals. com/jh/index.php/jh/article/view/30

Fusté-Forné, F. and Jamal, T. (2020), "Slow food tourism: an ethical microtrend for the Anthropocene", Journal of Tourism Futures, Vol. 6 No. 3, pp. 227-232, doi: 10.1108/JTF-10-2019-0120.

Fusté-Forné, F. and Jamal, T. (2021), "Co-creating new directions for service robots in hospitality and tourism", Tourism and Hospitality, Vol. 2 No. 1, pp. 43-61, doi: 10.3390/tourhosp2010003.

Gössling, S., Scott, D. and Hall, C.M. (2021), "Pandemics, tourism and global change: a rapid assessment of COVID-19", Journal of Sustainable Tourism, Vol. 29 No. 1, pp. 1-20, doi: 10.1080/ 09669582.2020.1758708.

Gretzel, U., Fuchs, M., Baggio, R., Hoepken, W., Law, R., Neidhardt, J., Pesonen, J., Zanker, M. and Xiang, Z. (2020), "E-tourism beyond COVID-19: a call for transformative research", Journal of Information Technology and Tourism, Vol. 22, pp. 187-203, doi: 10.1007/s40558-020-00181-3.

Handley, L. (2020), 'Robot waiters, mannequins and rooftop dining: how we'll start to go to restaurants again", CNBC, May 25, available at: www.cnbc.com/2020/05/25/how-well-start-to-go-to-restaurantsafter-coronavirus-lockdowns.html

Hong Zhu, D. and Ping Chang, Y. (2020), "Robot with humanoid hands cooks food better?", International Journal of Contemporary Hospitality Management, Vol. 32 No. 3, pp. 1367-1383, doi: 10.1108/IJCHM-102019-0904.

Hontoria, N. (2020), "Anti-covid: restaurantes con robots como camareros", Crónica Global, June 16, available at: https://cronicaglobal.elespanol.com/cronica-directo/curiosidades/restaurantes-robotscamareros_355800_102.html

International Federation of Robotics (2020), "Service robots", available at: https://ifr.org/service-robots

Ivanov, S. and Webster, C. (2019), Robots, Artificial Intelligence and Service Automation in Travel, Tourism and Hospitality, Emerald Publishing, Bingley.

Ivanov, S., Gretzel, U., Berezina, K., Sigala, M. and Webster, C. (2019), "Progress on robotics in hospitality and tourism: a review of the literature", Journal of Hospitality and Tourism Technology, Vol. 10 No. 4, pp. 489-521, doi: 10.1108/JHTT-08-2018-0087.

Ivanov, S., Webster, C., Stoilova, E. and Slobodskoy, D. (2020), "Biosecurity, crisis management, automation technologies, and economic performance of travel, tourism and hospitality companies - a conceptual framework", Tourism Economics, Vol. ahead-of-print No. ahead-of-print, pp. 1-24, doi: $10.1177 / 1354816620946541$.

Jamal, T. (2019), Justice and Ethics in Tourism, Routledge, Abingdon.

Jamal, T. and Budke, C. (2020), "Tourism in a world with pandemics: local-global responsibility and action", Journal of Tourism Futures, Vol. 6 No. 2, pp. 181-188, doi: 10.1108/JTF-02-2020-0014.

Korstanje, M. (2020), "El nacimiento de la anti-hospitalidad: no debemos confiar en los robots", Revista Turismo: Estudos e Práticas, Vol. 9 No. 1, pp. 1-11, available at: http://natal.uern.br/periodicos/index. php/RTEP/article/view/646

Kuo, C.-M., Chen, L.-C. and Tseng, C.-Y. (2017), "Investigating an innovative service with hospitality robots", International Journal of Contemporary Hospitality Management, Vol. 29 No. 5, pp. 1305-1321, doi: 10.1108/IJCHM-08-2015-0414. 
Lafranca, L.R.S. (2020), Humans and Robots in Times of Quarantine Based on First-Hand Accounts, University of Twente, Twente.

Lang, N. (2021), "Robots serve up safety in restaurants", Food Safety Tech, March 1, available at: https:// foodsafetytech.com/column/robots-serve-up-safety-in-restaurants/

Lee, W.H., Lin, C.W. and Shih, K.H. (2018), "A technology acceptance model for the perception of restaurant service robots for trust, interactivity, and output quality", International Journal of Mobile Communications, Vol. 16 No. 4, pp. 361-376, doi: 10.1504//JMC.2018.092666.

Littman, J. (2021), "88\% of restaurants considering swapping to digital menus, survey says", Restaurant Dive, February 24, available at: www.restaurantdive.com/news/88-of-restaurants-considering-swappingto-digital-menus-survey-says/595558/

Manthiou, A., Klaus, P., Kuppelwieser, V.G. and Reeves, W. (2020), "Man vs machine: examining the three themes of service robotics in tourism and hospitality", Electronic Markets, Vol. ahead-of-print No. ahead-of-print, pp. 1-17, doi: 10.1007/s12525-020-00434-3.

Mende, M., Scott, M.L., van Doorn, J., Grewal, D. and Shanks, I. (2019), "Service robots rising: how humanoid robots influence service experiences and elicit compensatory consumer responses", Journal of Marketing Research, Vol. 56 No. 4, pp. 535-556, doi: 10.1177/0022243718822827.

Müller, V.C. (2020), "Ethics of artificial intelligence and robotics", The Stanford Encyclopedia of Philosophy, April 30, available at: https://plato.stanford.edu/entries/ethics-ai/

Murphy, J., Hofacker, C. and Gretzel, U. (2017), "Dawning of the age of robots in hospitality and tourism: challenges for teaching and research", European Journal of Tourism Research, Vol. 15, pp. 104-111, available at: https://ejtr.vumk.eu/index.php/about/article/view/265

Nepal, S.K. (2020), "Adventure travel and tourism after COVID-19-business as usual or opportunity to reset?”, Tourism Geographies, Vol. 22 No. 3, pp. 646-650, doi: 10.1080/14616688.2020.1760926.

Park, S. (2020), "Multifaceted trust in tourism service robots", Annals of Tourism Research, Vol. 81, pp. 1-12, doi: 10.1016/j.annals.2020.102888.

Pransky, J. (1996), "Service robots-how we should define them?", Service Robot: An International Journal, Vol. 2 No. 1, pp. 4-5.

Prayag, G. (2020), "Time for reset? COVID-19 and tourism resilience", Tourism Review International, Vol. 24 Nos 2-3, pp. 179-184, doi: 10.3727/154427220X15926147793595.

Qiu, H., Li, M., Shu, B. and Bai, B. (2020), "Enhancing hospitality experience with service robots: the mediating role of rapport building", Journal of Hospitality Marketing and Management, Vol. 29 No. 3, pp. 247-268, doi: 10.1080/19368623.2019.1645073.

Royal Caribbean International (2016), "Robot bartenders shake things up at sea", September 20, available at: www.royalcaribbean.com/blog/robot-bartenders-shake-things-up-at-sea/

Semenza, J.C. and Ebi, K.L. (2019), "Climate change impact on migration, travel, travel destinations and the tourism industry", Journal of Travel Medicine, Vol. 26 No. 5, taz026, doi: 10.1093/jtm/taz026.

Seyitoğlu, F. and Ivanov, S. (2020a), "Understanding the robotic restaurant experience: a multiple case study", Journal of Tourism Futures, Vol. ahead-of-print No. ahead-of-print, pp. 1-18, doi: 10.1108/JTF-04-2020-0070.

Seyitoğlu, F. and Ivanov, S. (2020b), "Service robots as a tool for physical distancing in tourism", Current Issues in Tourism, Vol. 24 No. 12, pp. 1631-1634, doi: 10.1080/13683500.2020.1774518.

Seyitoğlu, F. and Ivanov, S. (2020c), "A conceptual framework of the service delivery system design for hospitality firms in the (post-)viral world: the role of service robots", International Journal of Hospitality Management, Vol. 91, 102661, doi: 10.1016/j.jijhm.2020.102661.

Sigala, M. (2020), "Tourism and COVID-19: impacts and implications for advancing and resetting industry and research", Journal of Business Research, Vol. 117, pp. 312-321, doi: 10.1016/j.jbusres. 2020.06.015.

Thomas, Z. (2020), "Coronavirus: will Covid-19 speed up the use of robots to replace human workers?", $B B C$, April 19, available at: www.bbc.com/news/technology-52340651

Tuomi, A., Tussyadiah, I.P. and Stienmetz, J. (2020), "Applications and implications of service robots in hospitality”, Cornell Hospitality Quarterly, Vol. 62 No. 2, pp. 232-247, doi: 10.1177/1938965520923961.

Tussyadiah, I.P., Zach, F.J. and Wang, J. (2020), "Do travelers trust intelligent service robots?", Annals of Tourism Research, Vol. 81, pp. 1-14, doi: 10.1016/j.annals.2020.102886. 
UNWTO (2020), "International tourism and COVID-19", available at: www.unwto.org/internationaltourism-and-covid-19

Van Doorn, J., Mende, M., Noble, S.M., Hulland, J., Ostrom, A.L., Grewal, D. and Petersen, J.A. (2017), "Domo arigato Mr. Roboto: emergence of automated social presence in organizational frontlines and customers' service experiences", Journal of Service Research, Vol. 20 No. 1, pp. 43-58, doi: 10.1177/ 1094670516679272

Van Wynsberghe, A. and Sharkey, N. (2020), "Special issue on responsible robotics: introduction", Ethics and Information Technology, Vol. 22, pp. 281-282, doi: 10.1007/s10676-020-09562-y.

Webster, C. and Ivanov, S. (2020), "Demographic change as a driver for tourism automation", Journal of Tourism Futures, Vol. 6 No. 3, pp. 263-270, doi: 10.1108/JTF-10-2019-0109.

Wiggers, K. (2020), "Sony Al launches the gastronomy flagship project to apply Al to cooking", Venture Beat, December 14, available at: https://venturebeat.com/2020/12/14/sony-ai-launches-the-gastronomyflagship-project-to-apply-ai-to-cooking/

Zemke, D.M.V., Tang, J., Raab, C. and Kim, J. (2020), "How to build a better robot ... for quick-service restaurants", Journal of Hospitality and Tourism Research, Vol. 44 No. 8, pp. 1235-1269, doi: 10.1177/ 1096348020946383.

Zeng, Z., Chen, P.J. and Lew, A.A. (2020), "From high-touch to high-tech: COVID-19 drives robotics adoption", Tourism Geographies, Vol. 22 No. 3, pp. 724-734, doi: 10.1080/14616688.2020.1762118.

Zhu, D.H. and Chang, Y.P. (2020), "Robot with humanoid hands cooks food better? Effect of robotic chef anthropomorphism on food quality prediction", International Journal of Contemporary Hospitality Management, Vol. 32 No. 3, pp. 1367-1383, doi: 10.1108/IJCHM-10-2019-0904.

\section{Corresponding author}

Francesc Fusté-Forné can be contacted at: researchexperiencetourism@gmail.com; francesc.fusteforne@udg.edu

For instructions on how to order reprints of this article, please visit our website: www.emeraldgrouppublishing.com/licensing/reprints.htm

Or contact us for further details: permissions@emeraldinsight.com 